\title{
Legal status of direct sales of agricultural and food products in the legislation of selected EU Member States**
}

\section{Introduction}

The legal status of direct sales of agricultural products is not determined by the EU legislator. Member States are free to adopt their provisions in this regard. However, the Common Agricultural Policy 2013-2020 provided support for "developing direct sales and local markets" and improving the functioning of the food supply chain. ${ }^{1}$ The term "short supply chain," of which direct sales is the simplest form, has been defined in EU law for the first time in article 2 of Regulation (EU) No 1305/2013 on support for rural development by the European Agricultural Fund for Rural Development (EAFRD), ${ }^{2}$ and complemented by article 11 of European Commission Delegated Regulation (EU) No 807/2014 supplementing the Rural Development Regulation. ${ }^{3}$

* Instytut Nauk Ekonomicznych, Uniwersytet Przyrodniczy we Wrocławiu.

** This work was supported by the National Science Centre in Poland under grant No 2016/21/D/HS5/03906.

${ }^{1}$ Communication from the Commission to the European Parliament, the Council, the European Economic and Social Committee and the Committee of the Regions, "The CAP towards 2020: Meeting the food, natural resources and territorial challenges of the future," Brussels, 18.11.2010, $\operatorname{COM}(2010) 672$ final.

2 OJ EU L 347, 20.12.2013.

${ }^{3}$ Commission Delegated Regulation (EU) No 807/2014 of 11 March 2014 supplementing Regulation (EU) No 1305/2013 of the European Parliament and the Council on support for rural development by the European Agricultural Fund for Rural Development (EAFRD) and introducing transitional provisions, OJ L 227, 31.07.2014. 
The post-2020 CAP legislative proposal, lists, inter alia, "the promotion of short supply chain and local markets" as an aspect of a cooperation between at least two entities which should be covered by support, ${ }^{4}$ and within the CAP objective "to improve the farmers' position in the value chain," aims, for example, to increase fruit and vegetable concentration of supply and the placing on the market, including through direct marketing. ${ }^{5}$ The role that direct sales of agricultural products play in the agricultural producer's activity and in the development of short supply chains and local markets justifies the selection of the research topic.

It is interesting to investigate how EU Member States determine the definition of direct sales and whether the law contributes to the undertaking of this activity by farmers. It should occupy a precisely defined place among the activities carried out by the agricultural producer. It is in fact the natural final stage of agricultural production. ${ }^{6}$ Therefore, the purpose of the considerations is to determine the legal status of direct sales in the selected EU countries legislations: Poland, Italy, and France, including its place in the field of agricultural activity.

The analysis of Polish law may be useful because of the recently issued provisions dedicated specifically to direct sales. ${ }^{7}$ Whereas, in Italian law, direct marketing has a long tradition and it is specified in detail by a separate regulation. France, similarly to Italy, has a broad concept of agricultural activities in which direct marketing is included. The subject of direct sales in Italian law has been extensively discussed in the Italian

${ }^{4}$ Recital 45 of the Proposal for a Regulation of the European Parliament and of the Council establishing rules on support for strategic plans to be drawn up by the Member States under the Common agricultural policy (CAP Strategic Plans) and financed by the European Agricultural Guarantee Fund (EAGF) and by the European Agricultural Fund for Rural Development (EAFRD) and repealing Regulation (EU) No 1305/2013 of the European Parliament and of the Council and Regulation (EU) No 1307/2013 of the European Parliament and of the Council, COM/2018/392 final -2018/0216 (COD).

${ }^{5}$ Article 42 b) Proposal for a Regulation of the European Parliament and of the Council establishing rules on support for strategic plans to be drawn up by Member States under the Common agricultural policy (...).

${ }^{6}$ R. Budzinowski, Nowa definicja przedsiębiorcy rolnego we wtoskim kodeksie cywilnym, "Studia Iuridica Agraria" 2002, Vol. III, p. 101; idem, Prawne pojęcie działalności rolniczej, "Prawo i Administracja" 2003, Vol. II, p. 167 et seq.

7 The currently applicable regulation of direct sales (and more specifically of ,agricultural retail trade") in Polish law has been discussed in: A. Kapała, Agricultural retail trade regulation as a legal instrument to support local food systems, "European Food and Feed Law Review" 2020, Vol. 15, No. 3, pp. 231-236. 
doctrine, ${ }^{8}$ likewise, it was analysed in French literature, in relation to French law, especially by L. Bodiguel. ${ }^{9}$

\section{Direct sales status in Polish law}

Poland, giving a response to the growing interest of consumers in the short supply chains, has adopted regulations on "agricultural retail trade" aimed to enhance the sales of food produced by farmers on their farms to final consumers. ${ }^{10}$ Under those provisions farmers can sell directly, preserving their agricultural status, raw and processed products of plant and animal origin, as well as complex products.

Although this activity has been covered by special provisions, it has not been included in any of the definitions of agricultural activity in Polish law. ${ }^{11}$ The concept of agricultural activity laid down in the provisions of business law and formulated to distinguish it from other business activities is limited to agricultural production activities in the field of crops, animal husbandry and farming, horticulture, vegetable growing, forestry and inland fisheries. ${ }^{12}$

${ }^{8}$ Among many see for example: F. Albisinni, La vendita diretta dei prodotti agricoli, in: L. Costato, A. Germanò, E. Rook Basile (eds.), Manuale di diritto agrario, Torino 2011, pp. $263-$ 294; idem, Commento all'art. 4 d. lgs. 228/2001, "Le Nuove Leggi Civili Commentate" 2001, No. 3-4, pp. 754-763; M.R. Alabrese, La vendita diretta dei prodotti agricoli, "Rivista di Diritto Alimentare" 2008, No. 3, pp. 3-8; S. Bolognini, Vendita diretta dei prodotti agricoli, in: Digesto delle discipline privatistiche. Sezione civile, vol. IV, Torino 2011, pp. 503-619; G. Cigarini, Vendita diretta di prodotti agricoli, in: N. Irti (ed.) Dizionari del diritto privato, (ed.) A. Carozza, Diritto agrario, Milano 1983, p. 899; E. Cristiani, La vendita diretta di prodotti con metodo biologico, "Rivista di Diritto Alimentare" 2008, No. 3, p. 5 et seq.; A. Germanò, Commento all'art. 4 d. lgs. n. 228/2001, "Rivista di Diritto Agrario" 2002, No. 1, p. 276 et seq.

${ }^{9}$ L. Bodiguel, M. Cardwell, Evolving definitions of "agriculture" for an evolving agriculture?, “The Conveyancer and Property Lawyer" 2005, No. 5, pp. 419-446; eidem, Évolution de la définition de l'agriculture pour une agriculture évoluée. Approche comparative Union europeennel Grande Bretagne/France, "Revue du Marché commun et de l'Union européenne" 2005, No. 490, pp. 456-466.

${ }^{10}$ Agricultural retail trade was introduced into the Polish legislation by the Act of 16 November 2016 on amending certain acts to facilitate the sale of food by farmers (Journal of Laws 2016, item 1961).

${ }^{11}$ In Polish law, there are a number of definitions of agricultural activity established for the purposes of various acts (tax, social insurance, agricultural system). See more: D. Łobos-Kotowska, Działalność rolnicza w przepisach prawa publicznego i prywatnego, "Studia Iuridica Agraria" 2014, Vol. 59, pp. 217-229; T. Kurowska, Miejsce i rola działalności rolniczej w prawie rolnym, "Studia Iuridica Agraria" 2017, Vol. 15, pp. 47-74.

${ }_{12}$ Article 6, § 1(1) The Act of March 6, 2018, Entrepreneurs' Law (consolidated text: Journal of Laws 2019, item 1292, as amended). 
Farmers engaged in this activity have a privileged position both under the regulations of business law, ${ }^{13}$ tax law $^{14}$ and social law. ${ }^{15}$ They are not regarded as entrepreneurs and therefore do not have to register their business, nor do they incur income taxes thereof, since the agricultural activity is not subject to this tax. ${ }^{16}$ In addition, they can benefit from a separate, more privileged social insurance system for farmers, which allows them to pay significantly lower contributions, compared to those paid by entrepreneurs. ${ }^{17}$

Although the "agricultural retail trade" is not an agricultural activity, it has been exempted from the business law regime and can be carried out by the farmer without any obligation to register a business. ${ }^{18}$ Hence, farmers conducting such activities do not lose their privileged legal status and do not become entrepreneurs. They can still benefit from the agricultural social insurance, tax exemptions, and other simplifications which certainly strengthen their market position in competition with food businesses and are an incentive to undertake and conduct the activity of food sales discussed.

The legislator has set a series of conditions for conducting "agricultural retail trade" to ensure that this special regulation is addressed to agricultural households and not to intermediaries or food industry businesses. One of the conditions is that the processing of food ought to be done in a manner "other than industrial." The Act does not define how this term should be understood. It might be assumed that this means processing without the use of production lines or technology-specific for large-scale production and processing.

13 Ibidem.

14 Tax law provides a distinct definition of agricultural activity: see article $2 \S 2$ of the Act of July 26, 1991 on personal income tax (consolidated text: Journal of Laws 2019, item 1387, as amended).

15 According to the social insurance law, a key criterion to be subject to the farmers' social insurance is to have a status of the farmer. It means, pursuant to article 6(1) of the Act of 20 December 1990 on the social insurance of farmers (consolidated text: Journal of Laws 2020, item 174) a natural person, who in person and on its own, conducts an agricultural activity on the farm being in its possession. See more on agricultural social insurance: D. Puślecki, Przedmiot ochrony jako przesłanka zachowania odrębnego subsystemu ubezpieczenia społecznego rolników, "Przegląd Prawa Rolnego" 2017, No. 2, pp. 31-50; idem, Przedmiot ochrony jako przesłanka zachowania odrębnego subsystemu ubezpieczenia społecznego rolników, "Studia Iuridica Lublinensia" 2017, Vol. 26, No. 1, pp. 433-443.

${ }^{16}$ Pursuant to article $2 \S 1(1)$ of the act on personal income tax. See more J. Bieluk, Podatek dochodowy $w$ działalności rolniczej, "Studia Iuridica Agraria" 2007, Vol. VI; idem, Pojęcie działalności rolniczej $w$ ustawie o podatku dochodowym od osób fizycznych i osób prawnych, "Przegląd Prawa Rolnego" 2008, No. 2, pp. 181-194.

17 See more on Polish agricultural law: A. Lichorowicz, Les origines et l'histoire du droit rural polonaise, in: Nascita e sviluppo del diritto agrario come legislazione e come scienza. Dal regime fondiario al diritto della produzione agricola, Pisa 1992.

18 Article $6 \S 1(4)$ of the act on personal income tax. 
A great advantage that the regulation gives to the farmers is the possibility to purchase products from outside their farms in order to produce food. However, the final product should consist of at least $50 \%$ of plant or animal products originating from their farm, without counting the water. This solution allows farmers to produce a wide range of food, including complex products and ready meals. According to the next requirement, the processing and sales of products ought to be, with some exceptions, conducted without intermediaries, i.e. personally by the farmer or members of his household. Another limitation is that food can only be sold to final consumers (throughout the country), retail stores, and other entities, like local restaurants, schools, etc., delivering food to final consumers, though only to those located in the same province as the farm. ${ }^{19}$

In terms of income tax, the income from agricultural retail trade is not considered agricultural, but it is exempted from personal income tax if it fails to exceed PLN 40,000 a year (about $8815 €$ ). Annual income above that limit is taxed at only $2 \% .^{20}$

\section{Legal status of direct sales in Italy}

Article 2135 of the Italian Civil Code provides a list of activities regarded as agricultural activities and the marketing of agricultural products is expressis verbis listed as an activity "connected" to agricultural activity (attività connessa).$^{21}$ The definition is broad and distinguishes two categories of activities carried out by an agricultural entrepreneur: agricultural activity based on the biological cycle criterion (soil cultivation, forestry, animal husbandry) and connected activities. The latter include various commercial activities which, having met the principle of connection with the farming activity, are classified as agricultural under the Italian Civil Code. An agricultural entrepreneur carrying out the "connected" activities retains his special, privileged status over the one of a commercial entrepreneur. ${ }^{22}$

19 Pursuant to hygiene requirements contained in article 44a $\S 1$ point 1 of the Act of August 25, 2006 on food and nutrition safety (consolidated text: Journal of Laws 2019, item 1252, as amended).

${ }^{20}$ Article $21 \S 1$ (71a) of the act on personal income tax.

${ }^{21}$ Codice Civile Regio Decreto 16 marzo 1942, n. 262. Approvazione del testo del Codice civile (Gazzetta Ufficiale No 79 of 4.04.1942, as amended).

${ }_{22}$ About the Italian concept of agricultural entrepreneur in Polish literature see: R. Budzinowski, Nowa definicja przedsiębiorcy rolnego we wtoskim kodeksie cywilnym, "Studia Iuridica Agraria" 2002, Vol. III, p. 91 et seq.; idem, Prawne pojęcie działalności rolniczej, "Prawo i Administracja" 2003, Vol. II, pp. 172-177; A. Lichorowicz, Gospodarstwo rolne a kodeks handlowy, "Przegląd 
To meet the principle of connection, the marketing of agricultural or food products ought to be performed alongside the agricultural entrepreneur's basic activity such as soil cultivation, forest cultivation, or animal husbandry, as referred to in article 2135 of the Civil Code. Products being subjected to manipulation, conservation, transformation, marketing or enhancement should originate mainly from the basic agricultural activity. Thus, the criterion of the prevailing origin of farm products is required. In other words, the agricultural entrepreneur, in addition to agricultural products manufactured by himself, may also sell, in a non-dominant quantity, purchased products.

The legislator has also classified as agricultural manipulation, the conservation, transformation, and enhancement of products. Therefore, the subject of sale can be both agricultural products in unprocessed and processed state obtained mainly from basic agricultural activities. ${ }^{23}$ The law no longer prescribes that the connected activities, in order to be agricultural, must fall within "the normal exercise of agriculture," as was the case in the past. So there are no more limits on the manner in which the activity is carried out, on the means used, or the techniques adopted which may, therefore, also be industrial.

Retail direct sales of agricultural products are subject to special regulations, i.e. article 4 of the legislative decree of 18 May 2001 No. $228^{24}$ which confirms that the commercial regulation does not apply to direct retail sales (except for the provisions on the allocation of stands and the occupation of space). ${ }^{25}$ It will apply, though, if the amount of direct sales of non-farm products exceeds EUR 160,000 for individual entrepreneurs or EUR 4 million for companies. ${ }^{26}$

Ustawodawstwa Gospodarczego" 1988, No. 7-8, p. 14 et seq.; idem, Przedsiębiorstwo handlowe a przedsiębiorstwo rolne we włoskim kodeksie cywilnym, in: E. Nowińska, M. du Vall (eds.), Księga pamiątkowa ku czci profesora Janusza Szwaji, Kraków 2004, p. 241 et seq.; A. Szymecka, Przedsiębiorstwo rolne we włoskim systemie prawnym (I), "Przegląd Prawa Rolnego" 2007, No. 2, pp. 177-202; eadem, Przedsiębiorstwo rolne we włoskim systemie prawnym (II), "Przegląd Prawa Rolnego" 2008, No. 1, p. 199 et seq.

${ }^{23}$ S. Bolognini, Commento all'art. 10 (Trasformazione e vendia dei prodotti), "Le Nuove Leggi Civili Commentate" 2007, No. 1-2, p. 217.

${ }^{24}$ The commercial regulation is contained in: Decreto Legislativo 18 maggio 2001, n. 228 "Orientamento e modernizzazione del settore agricolo, a norma dell'articolo 7 della legge 5 marzo 2001, No. 57" (Gazzetta Ufficiale No 137 of 15.06.2001, Supplemento Ordinario No 149 as amended; hereinafter referred to as d. lgs. 228/2001).

${ }^{25}$ Provisions on direct sales activities are contained in: Decreto Legislativo 31 marzo 1998, n. 114 "Riforma della disciplina relativa al settore del commercio, a norma dell'articolo 4, comma 4, della legge 15 marzo 1997, n. 59" (Gazzetta Ufficiale No 95 of 24.04.1998, Supplemento Ordinario No 80, as amended).

${ }^{26}$ Article 4(8) d. lgs. 228/2001. 
Regarding the goods that can be the subject of sale, article 4(1) d. lgs. 228/2001 stipulates that agricultural entrepreneurs may sell directly plant and animal products coming mainly from their own farms, in compliance with hygiene and sanitary regulations. This wording is in accordance with article 2135(3) of the Italian Civil Code, which applies the prevailing origin of farm products parameter in relation to marketing and activities carried out on products.

Additionally, article 4(5) d. lgs. 228/2001 provides that the regulation of direct sales also applies to processed products obtained as a result of the processing and manipulation of agricultural and animal products "whose purpose is to make full use of the enterprise's production cycle." Therefore, and agricultural entrepreneurs can make direct sales of products in natural state predominantly produced on their own farm, but also derived products obtained as a result of manipulation or processing also made on their own farm, as well as acquired products (in a quantity outweighing their own products).

The sale of these types of products is not subject to any permit or other form of regulation. In the case of sales in the itinerant and electronic form or in public places, it is required to report this activity to the municipality. As for the forms of direct sales, agricultural entrepreneurs (individual or associated) can directly sell their own products in the itinerant form in the whole of Italy (article 4(2) d. lgs. 228/2001), as well as at fixed points "in public areas or in premises open to the public" (article 4(4) d. lgs. 228/2001). Another form is electronic sales and direct retail sales carried out on open areas within a farm or other land owned by an agricultural entrepreneur.

What is more, in the context of direct sales, immediate consumption of the products being sold is allowed, using the premises and furnishings in the availability of the agricultural entrepreneur, with the exclusion of the waiter service and with the observance of the general hygienic-sanitary requirements.$^{27}$ It should be added that the national regulation in question has a framework character. Regarding direct sales, the regions have legislative powers and can detail the general principles set out in national law.

The taxation of agricultural enterprises is treated in a privileged way by Italian tax law. In the field of personal income tax, articles 32 and 34 of the Decree of the President of the Republic of 1986 No. 917 on income tax ${ }^{28}$ contain a special regulation on agricultural income that applies to basic agricultural activities as well as to connected agricultural activities, but

27 Article 4 (8bis) d. lgs. 228/2001.

${ }^{28}$ Testo unico delle imposte sui redditi (TUIR) di cui al Decreto del Presidente della Repubblica No. 917/1986 (Gazzetta Ufficiale No 302 of 31.12.1986, Supplemento Ordinario, as amended). 
only to the processing, storage, manipulation, marketing and enhancement of products obtained mainly from soil or forest cultivation or animals husbandry, provided that these products belong to the catalogue of products specified in the ministerial decree..$^{29}$ Income from direct sales qualifies as agricultural (subject to cadastral taxation in accordance with article 34 of the income tax decree), if a product, being a result of connected activity consisting in processing, is included in the List of the Ministerial Decree.

\section{Direct sales status in French law}

Direct sale of agricultural products is not subject to a separate regulation in French law and expressis verbis is not mentioned in the definition of agricultural activity. However, it is included, through interpretation, into the concept of agricultural activity as defined in article L.311-1 of the Code rural. ${ }^{30}$ The definition distinguishes two types of agricultural activity: traditionally understood as agricultural, defined in the doctrine par nature and agricultural activity par relation or dérivées (also referred to as accessoires), ${ }^{31}$ taking into account the farm diversification and multi-activity. ${ }^{32}$

Typical agricultural activity (par nature) is based on the criterion of the biological cycle. It includes "all the activities corresponding to the harnessing and the exploitation of a biological cycle of vegetable or animal character and constitutes one or more stages necessary for the progress of this cycle." Derived agricultural activity (par relation) includes "activities carried out by a farmer (exploitant agricole) that constitute an extension of the act of production or are to support a farm." These are various activities, often of a "commercial" nature, which, however, benefit from the special treatment accorded by rural law to agricultural activities, if they are carried out under several predetermined conditions. ${ }^{33}$ Direct sales as well as the processing of

${ }^{29}$ Currently biding is: Decreto 13 febbraio 2015 Individuazione dei beni che possono essere oggetto delle attività agricole connesse, di cui all'articolo 32 , comma 2, lettera c), del testo unico delle imposte sui redditi (Gazzetta Ufficiale No. 62 of 16.03.2015, Serie Generale).

${ }^{30}$ Code rural et de la pêche maritime, version consolidée au 14 avril 2020, article L. 311-1 as amended by LOI n ${ }^{\circ}$ 2019-469 du 20 mai 2019 - article 4(V) (Journal Officiel de la République Française No 0117, 21.05.2019).

${ }_{31}$ L. Bodiguel, M. Cardwell, Evolving definitions of “agriculture”..., p. 430.

32 V. Barabé-Bouchard, M. Hérail, Droit rural, Paris 2011, p. 6.

33 The activities, thus very broadly defined, present a civil character. They, therefore, fall within the jurisdiction of the civil courts and not that of the commercial courts, cit. Mémento Agriculture 2017-2018, Levallois 2016, p. 13. 
agricultural products obtained on the farm are recognized, by interpretation, as belonging to the second category of agricultural activity, being an extension of the act of production..$^{34}$

However, derived agricultural activity is recognized as such not because of a precise definition of its place by law, but on the basis of case law. As noted by L. Bodiguel, French law, due to its Latin tradition, favours general definitions, which require interpretation, rather than enumerative lists. The reference point for their interpretation are judgments of, in particular, the State Council or the Court of Cassation. ${ }^{35}$

What criteria must be met for the activity to be considered an agricultural derivative? One condition results directly from article L. 311-1 of the Code rural. The activity should be carried out by persons who already have the status of a farmer (exploitant agricole), due to their activity based on the biological cycle criterion. ${ }^{36}$ Other criteria were further specified in the jurisprudence, according to which, to fall under the notion of the activity of an "extension of the production act," direct sales must be conducted simultaneously on the same farm with an agricultural activity by nature. If this is the case, this activity will not be considered an act of commerce but it remains within the sphere of agriculture. ${ }^{37}$ The condition of inseparability from the agricultural activity by nature must, therefore, be met. ${ }^{38}$ Otherwise, the activity being an extension or having the farm as support will come under commercial law or another civil law branch. ${ }^{39}$

${ }^{34}$ V. Barabé-Bouchard, M. Hérail, Droit rural, p. 7; D. Krajeski, Droit rural, Issy-les-Moulineaux 2016, p. 19 ; L. Bodiguel, M. Cardwell, Évolution de la définition de l'agriculture..., p. 458.

${ }^{35}$ L. Bodiguel, M. Cardwell, Evolving definitions of "agriculture"..., p. 430 ; eidem, Évolution de la définition de l'agriculture..., p. 458.

${ }^{36}$ Mémento Agriculture 2017-2018, p. 14.

${ }^{37}$ L. Bodiguel, M. Cardwell, Evolving definitions of "agriculture”..., p. 432; eidem, Évolution de la définition de l'agriculture..., p. 459 and see there endnote 48, in which the authors give rulings regarding the condition of coexistence of agricultural activities par nature, like for instance: Cour Administrative d'Appel de Bordeaux, du 9 octobre 2001, published in "Recueil Lebon" ${ }^{\circ}$ 99BX02611; Cour de Cassation, Chambre Sociale, du 6 décembre 2001, published in "Bulletin Cassation" $n^{\circ}$ 5130; Cour de Cassation, Chambre Sociale, du 11 juillet 2002, published in "Revue de Droit Rural", février 2003, n 310.

${ }^{38}$ L. Bodiguel, who points out that the sale of agricultural products must "inextricably bound up with an activité agricole par nature: L. Bodiguel, M. Cardwell, Evolving definitions of "agriculture"..., p. 433.

${ }^{39}$ L. Bodiguel, M. Cardwell, Évolution de la définition de l'agriculture..., p. 456, who provides rulings: Cour de Cassation Chambre Sociale, 6 décembre 2001, published in "Bulletin Cassation" 2001, n 5130 (conditionneuse de légumes); D. Krajeski, Droit rural, p. 19. 
In relation to direct sales, the qualifying condition is, additionally, the origin of the products being in a sale. The processing or sale of products bought from third parties, if there is no link with an intervention in the biological cycle after their purchase, cannot be considered as an extension of the production act, but is a commercial activity. ${ }^{40}$ Therefore, as a general rule, the packaging and processing of agricultural products purchased from third parties, even if they are farmers, do not qualify as agricultural activities par relation. ${ }^{41}$

However, the exteriority of certain products, if they constitute necessary and minority additives that cannot be derived from agricultural activities, will not give rise to commercial activities. ${ }^{42}$ According to case-law, when two activities are economically related in such a way that one can be considered ancillary to the other, it is generally accepted that the additional activity, borrows the nature of the main activity. ${ }^{43}$ If the commercial activity carried out by the farmer is ancillary to the main farming activity, it takes the agricultural and civil nature of the main activity. ${ }^{44}$ The so-called "ancillary" character is based on three cumulative conditions: agricultural activities should prevail over commercial activities (for example, the farm production outweighs the external supply), both activities are coexisting, and ancillary activities are carried out in the interest of the main activity. ${ }^{45}$

Direct sales that meet these criteria remain in the sphere of agriculture, irrespectively of whether agricultural products have previously been processed and whether the sale takes place at a fixed point and with the help of specialised staff. ${ }^{46}$ The method of sale (direct sale to the consumer at a market, on the farm, via the catalogue, via the Internet), as well as the method of processing - industrial or simply artisanal - are irrelevant. ${ }^{47}$ In the doctrine, a judgment was highlighted, which considered that the existence

${ }^{40}$ Ibidem.

${ }^{41}$ Mémento Agriculture 2017-2018, p. 15 and see the ruling cited there: Cour de Cassation, Chambre Sociale, du 11 juillet 2002, n 00-16177, published in "Bulletin des Arrêts des Chambres Civiles" 2002 V, No. 252.

${ }^{42}$ L. Bodiguel, M. Cardwell, Évolution de la définition de l'agriculture..., p. 460 and the ruling cited there: Cour de Cassation, Chambre Sociale, du 23 mai 1991, pourvoi n ${ }^{\circ}$ 89-13.098. See also V. Barabé-Bouchard, M. Hérail, Droit rural, p. 8.

${ }^{43}$ Mémento Agriculture 2017-2018, p. 15 and the ruling cited there: Cour de Cassation, Chambre Civile, du 24 janvier 1865, published in "Dalloz Périodique" 1865, No. 1, p. 72.

${ }^{44}$ Ibidem. See also the ruling cited there: Cour de Cassation, Chambre Commerciale du 23 février 1983 n. 81-16.572, published in "Bulletin Civil de la Cour de Cassation" Vol. IV, No. 78.

${ }^{45}$ Ibidem.

${ }^{46}$ Ibidem, p. 14.

${ }^{47}$ Ibidem, p. 15; V. Barabé-Bouchard, M. Hérail, Droit rural, p. 8. 
of "a permanent installation specially designed to welcome customers" was not a sufficient circumstance to "prevent the sale of farm products from being regarded as the normal extension of agricultural activity." 48 According to another ruling, the farmer who sells his products at the market remains subject to the rural law regime ${ }^{49}$.

In the field of tax law, the definition from article L 311-1 of the Code rural is not applied. However, the criteria laid down for activities considered to be agricultural are generally very close to those used in agricultural tax law. The condition of farm support activities was taken over in tax law by applying a limit on the amount of income obtained from ancillary commercial and non-commercial activities. Farmers can retain the receipts coming from these activities, to determine the agricultural profits, if their average for the three calendar years preceding the opening date of the financial year does not exceed either $50 \%$ of the average agricultural receipts gained in the same period or 100,000 Euro. ${ }^{50}$

In French law, the social protection scheme for the self-employed in agricultural professions is applicable to persons engaged in the activities or on the holdings, enterprises or establishments listed in article L 722-1 of the Code rural. ${ }^{51}$ As regards activité accessoire, the protection applies to all forms of establishments managed by the farmer for the purpose of processing, packaging, and marketing of agricultural products, provided that these activities constitute an extension of the act of production. ${ }^{52}$

Synthetically, it can be said that in French law the agricultural qualification of the processing and marketing activity conducted by the farmer is based on the condition of its inseparability from the agricultural activity by nature, its ancillary character to the main activity and the prevailing origin of farm products. This activity is considered agricultural in civil law. Under tax law it enjoys a certain special treatment to a certain extent, as granted to agricultural activities. Social law provisions, too, allow the farmer who conducts it to benefit from the protection scheme established for "self-employed in agricultural professions."

${ }^{48}$ L. Bodiguel, M. Cardwell, Évolution de la définition de l'agriculture..., p. 460. See also the ruling cited by the authors: Cour Administrative d'Appel de Nantes, du 5 juillet 1989, published in "Recueil Lebon", n 89NT00191.

${ }^{49}$ Ibidem. See also the ruling cited there: Conseil d'Etat, du 29 décembre 1995, published in "Recueil Lebon" n’ 128613.

${ }^{50}$ Article 75 Code général des impôts arrêté du 6 avril 1950 (Journal Officiel de la République Française No 0103 of 30.04.1950).

${ }^{51}$ V. Barabé-Bouchard, M. Hérail, Droit rural, p. 17.

${ }^{52}$ L. Bodiguel, M. Cardwell, Evolving definitions of "agriculture”..., p. 431. 


\title{
5. Conclusions
}

To sum up the analysis, it can be said that in Polish law direct sale, defined as an "agricultural retail trade," is qualified as a non-agricultural business activity. However, if carried out in compliance with specified conditions, it is not subject to business law. A farmer conducting it retains his legal status and may continue to benefit from the facilities and exemptions provided for agricultural activities.

Italian law explicitly defines the status of direct sales as agricultural, situating it among connected agricultural activities carried out by the agricultural entrepreneur, and the detailed criteria for its connection with agricultural activity by nature are provided for in a separate special regulation. In French law, thanks to the broad definition of agricultural activity, although more general than Italian, the place of direct sales understood as an agricultural activity par relation, is defined by case law.

Each legislator chose a different way of determining the legal status of direct sales, although apparently the ratio legis was the same: to support this activity by enabling and facilitating farmers to carry it out. For, according to all three legislations, a farmer can make direct sales of unprocessed and processed products, while maintaining his privileged status under civil, commercial, tax and social law.

Naturally, there are some differences in the specification of the criteria. In Italy and France, the sale is allowed throughout the country and products originating from an own farm must be dominant, while in Poland they must constitute not less than $50 \%$ of the final product and the sale to the retail entities is limited to a province where the farm is located. The processing must be done rather in an artisanal way than industrial, while in France and Italy it is irrelevant.

\section{LEGAL STATUS OF DIRECT SALES OF AGRICULTURAL AND FOOD PRODUCTS IN THE LEGISLATION OF SELECTED EU MEMBER STATES}

\author{
Summary
}

The purpose of the discussion presented in the article was to determine the legal status of direct sale of agricultural and food products and its place in the agricultural activity in the legislation of selected EU Member States: Poland, Italy, and France. The considerations show that each legislator has chosen a different way of determining the legal status of this activity, though with a view to a similar ratio legis, which is to support it by enabling and 
facilitating farmers involvement. In Polish law, "agricultural retail sale" is outside the narrow definition of agricultural activity. It is not, however, subject to the provisions of business law provided it meets the conditions specified in law. Italian law defines the status of direct sales explicitly as agricultural, situating them among connected agricultural activities carried out by the agricultural entrepreneur. The detailed criteria for its connection with the agricultural activity by nature constitute a separate special regulation. In French law, thanks to the broad definition of agricultural activity, the place of direct sale as an agricultural activity par relation which is an extension of the act of production, is defined by case-law.

\section{LO STATUS GIURIDICO DELLA VENDITA DIRETTA DEI PRODOTTI AGRICOLI NELLA LEGISLAZIONE DI ALCUNI STATI MEMBRI DELL'UE SCELTI}

\section{Riassunto}

L'articolo si propone di stabilire lo status giuridico della vendita diretta dei prodotti agricoli e alimentari nella legislazione di alcuni Stati membri scelti, cioè in Polonia, Italia e Francia; compresa la collocazione della stessa nel settore dell'attività agricola. Le considerazioni svolte mettono in rilievo il fatto che ciascun legislatore ha scelto un modo diverso di definire lo status giuridico dell'attività in oggetto, anche se mosso da una ratio legis simile, cioè dal voler sostenerla dando agli agricoltori la possibilità di svolgerla e facilitandone lo svolgimento. Nel diritto polacco, la vendita diretta, definita come un "commercio agricolo al dettaglio", non rientra nella definizione ristretta di attività agricola. Essa non è soggetta nemmeno al diritto economico, sempre se soddisfa le condizioni stabilite dalla legge. Il diritto italiano, invece, definisce lo status di vendita diretta come agricola in maniera esplicita, collocandola tra le attività agricole connesse, svolte da un imprenditore agricolo, e stabilendo in una regolazione specifica separata $\mathrm{i}$ criteri per la connessione con l'attività agricola per sua natura. Nel diritto francese, grazie ad una definizione ampia di attività agricola, il luogo della vendita diretta, in quanto attività agricola par relation, intesa come continuazione dell'atto di produzione, è specificato dalla giurisprudenza. 